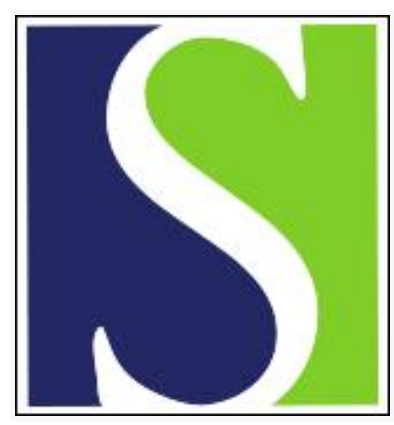

Scand J Work Environ Health 2005;31(6):459-464

https://doi.org/10.5271/sjweh.950

Issue date: 31 Dec 2005

Pleuropulmonary lesions, ergotamines and asbestos exposure by Hillerdal G, Rask-Andersen A

Affiliation: Department of Pulmonary Medicine, Karolinska University Hospital, SE-171 76, Stockholm, Sweden. gunnar.hillerdal@karolinska.se

Key terms: asbestos exposure; bromocriptine; ergotamine; literature review; methysergide; pleural effusion; pleuropulmonary lesion; registry study; systemic reaction

This article in PubMed: www.ncbi.nlm.nih.gov/pubmed/16425587

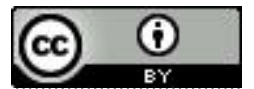




\title{
Pleuropulmonary lesions, ergotamines and asbestos exposure
}

\author{
by Gunnar Hillerdal, MD, ${ }^{1}$ Anna Rask-Andersen, $M D^{2}$
}

\begin{abstract}
Hillerdal G, Rask-Andersen A. Pleuropulmonary lesions, ergotamines and asbestos exposure. Scand J Work Environ Health 2005:31(6);459-464.

Objectives This study investigated the possibility of pleuropulmonary lesions, which can occur as rare but serious side effects of different ergot drugs, occurring more commonly in persons earlier exposed to asbestos. Methods All reports of pleuropulmonary side effects of the ergot drugs used in Sweden in the Swedish side effect registry from 1985 to 2003 were studied. In addition, the literature was reviewed.

Results In the registry, 47 men and 3 women were found. Of the men, 24 were exposed to asbestos, and 2 denied such exposure; 2 of the 3 women were exposed. In the literature, 111 patients were found- 32 had confirmed exposure and 15 denied it. For most of the patients, it was not possible to determine exposure.

Conclusions Enough evidence exists to postulate that earlier asbestos exposure in combination with the intake of ergot drugs can cause pleuropulmonary lesions.
\end{abstract}

Key terms bromocriptine; methysergide; literature review; pleural effusion; registry study; systemic reaction.

Ergotamines are a family of drugs that have potent effects on vasoconstriction and are also dopamine agonists. They are used for a variety of diseases: vascular headaches such as migraine (ergotamine, methysergide, cabergoline), hypotonia (dihydroergotamine), and Parkinson disease (bromochriptine, pergolide). A rare, but well-known side effect of these drugs is pleuropulmonary reactions. A few years ago, it was suggested that this particular side effect occurs more commonly in persons earlier exposed to asbestos $(1,2)$, which is also well known to cause lesions of both the pleura and the lung parenchyma. To investigate this intriguing connection between an occupational exposure and a drug given for medical reasons further, we decided to investigate all reports on the pleuropulmonary side effects of the ergot drugs used in Sweden in the Swedish Side Effect Registry. In addition, we made a literature review.

\section{Study population and methods}

The Swedish Registry for Side Effects of Medicines registers and evaluates all reported cases of suspected side effects from medical drugs prescribed by physicians.
Reports are made on a voluntary basis only, but all serious cases should be reported. Reported cases are evaluated at the registry office and additional information is, in most cases, demanded from the reporting physician, often including a copy of the patient report. The quality of the registry is high with an evaluation of the likelihood that the case has a connection with the suspected drug. All reports are computerized. The value of the registry has been shown in several publications, and the validity of the reports is high. Investigators can have access to the case reports in unidentified form. Unfortunately, in many cases, information on occupation and possible asbestos exposure is missing. The reports made before 1985 were very few and contained no pertinent data, and we therefore decided to accept only those from 1985 to 2003 . Thus all reports on the pleuropulmonary side effects of ergotamine drugs used in Sweden (ergotamine, dihydroergotamine, bromocriptine, cabergoline, and methysergide) were scrutinized; pergolide is not used in Sweden.

The reports from the registry were carefully studied. Only cases involving lesions of both pleura and lung were included in the study. For the ergot drugs, we noted dosages, how long the drug in question had been used, and when the symptoms first occurred. In particular, we

1 Department of Pulmonary Medicine, Karolinska University Hospital, Stockholm.

2 Department of Occupational and Environmental Diseases, Academic Hospital, Uppsala, Sweden.

Reprint requests to: Dr Gunnar Hillerdal, Department of Pulmonary Medicine, Karolinska University Hospital, SE-171 76, Stockholm, Sweden. [E-mail: gunnar.hillerdal@karolinska.se] 
determined whether the patient had been exposed to asbestos or not. Only if explicitly stated in the papers did we note asbestos exposure, all the others being classified as "unknown". The occupation of the patient was also noted.

For the literature review, PubMed was searched for all articles published in Western languages on the pleuropulmonary side effects of ergot drugs up to 2003 ("Ergot Alkaloids"[MeSH] AND "Respiratory Tract Diseases"[MeSH]). The articles were studied, and all earlier reports on the topic that could be found from 1968 on and not included in the search were also ordered. The articles were scrutinized for definite or possible former asbestos exposure of the patients. As in the registry study, pulmonary fibrosis alone or other side effects not including the pleura were disregarded.

Table 1. Asbestos exposure of 50 patients with pleuropulmonary side effects related to ergot alkaloids and reported to the Swedish Registry for Side Effects of Medical Drugs. No reports on methysergide were found.

\begin{tabular}{lccccc}
\hline Exposure & $\begin{array}{c}\text { Bromo- } \\
\text { criptine }\end{array}$ & $\begin{array}{c}\text { Dihydro- } \\
\text { ergo- } \\
\text { tamine }\end{array}$ & $\begin{array}{c}\text { Ergo- } \\
\text { tamine }\end{array}$ & $\begin{array}{c}\text { Caber- } \\
\text { goline }\end{array}$ & Total \\
\hline Men & 19 & 3 & 0 & 2 & 24 \\
Confirmed exposure & 2 & 0 & 0 & 0 & 2 \\
Denied exposure & 16 & 1 & 1 & 3 & 21 \\
Unknown exposure & 37 & 4 & 1 & 5 & 47 \\
Total & 1 & 0 & 1 a & 0 & 2 \\
Women & 0 & 0 & 0 & 0 & 0 \\
Confirmed exposure & 0 & 1 & 0 & 0 & 1 \\
Denied exposure & 1 & 1 & 1 & 0 & 3 \\
Unknown exposure & 38 & 5 & 2 & 5 & 50 \\
Total & & & & & \\
\hline Total & & & & & \\
\hline
\end{tabular}

a Paraoccupational exposure.

\section{Results}

\section{Registry study}

Forty-seven men and three women fulfilled the inclusion criteria. Of the men, 24 had confirmed exposure to asbestos, while, in two cases, such exposure was denied. For the remaining cases, possible exposure was not reported. Of the three women, two had confirmed exposure, one being paraoccupational (tables 1 and 2). The mean age of the patients was 65 (range 46-81) years. The latency from the first asbestos exposure and the start of the disease was three or more decades. The dosages used for the ergotamine drugs were within the normal range (table 3 ).

\section{Literature review}

Altogether 41 articles describing 111 patients were found. In most of them, exposure or nonexposure to asbestos was not possible to ascertain. For 32 patients, such exposure was confirmed, and for 15 it was denied (table 4).

\section{Discussion}

Swedish physicians are requested to report all serious and earlier unknown suspected side effects from prescribed medicines to the drug side-effect registry. Unfortunately, many pleural side effects are probably never diagnosed as due to ergotamines. The symptoms usually occur only after prolonged treatment with the drugas seen from table 3 , up to 25 years. This prolongation makes the connection less obvious to both the patient and the physician. Nevertheless, in most of the cases in

Table 2. Occupation and exposure to asbestos of the 50 patients with pleuropulmonary side effects related to ergot alkaloids and reported to the Swedish Registry for Side Effects of Medical Drugs.

\begin{tabular}{|c|c|c|c|c|c|c|c|c|c|c|c|c|c|c|c|c|c|c|}
\hline \multirow[t]{2}{*}{ Exposure } & \multicolumn{12}{|c|}{ Possible asbestos exposure } & \multicolumn{5}{|c|}{ Unlikely asbestos exposure } & \multirow{2}{*}{$\begin{array}{c}\text { Total } \\
(\mathrm{N}=50)\end{array}$} \\
\hline & $\begin{array}{l}\text { Const- } \\
\text { ruction } \\
\text { work } \\
(\mathrm{N}=9)\end{array}$ & $\begin{array}{c}\text { Plumb- } \\
\text { ing } \\
(\mathrm{N}=1)\end{array}$ & $\begin{array}{l}\text { Cellu- } \\
\text { lose } \\
\text { factory } \\
\text { work } \\
(\mathrm{N}=2)\end{array}$ & $\begin{array}{c}\text { Elect- } \\
\text { ronics } \\
(\mathrm{N}=1)\end{array}$ & $\begin{array}{l}\text { Auto } \\
\text { repair } \\
(N=1)\end{array}$ & $\begin{array}{l}\text { Iron } \\
\text { trade } \\
(\mathrm{N}=1)\end{array}$ & $\begin{array}{l}\text { Dock- } \\
\text { yard } \\
\text { work } \\
(\mathrm{N}=1)\end{array}$ & $\begin{array}{c}\text { Indus- } \\
\text { trial } \\
\text { work } \\
(\mathrm{N}=6)\end{array}$ & $\begin{array}{l}\text { Mach- } \\
\text { ine } \\
\text { work } \\
(\mathrm{N}=1)\end{array}$ & $\begin{array}{l}\text { Engine } \\
\text { repair } \\
(N=1)\end{array}$ & $\begin{array}{c}\text { Grind- } \\
\text { ing } \\
(N=1)\end{array}$ & $\begin{array}{l}\text { Do- } \\
\text { mestic } \\
\text { work } \\
(\mathrm{N}=1)\end{array}$ & $\begin{array}{l}\text { Print- } \\
\text { ing } \\
(N=2)\end{array}$ & $\begin{array}{c}\text { Office } \\
\text { work } \\
(\mathrm{N}=4)\end{array}$ & $\begin{array}{c}\text { Teach- } \\
\text { ing } \\
(N=1)\end{array}$ & $\begin{array}{l}\text { Sales } \\
(N=1)\end{array}$ & $\begin{array}{l}\text { Un- } \\
\text { known } \\
\text { occu- } \\
\text { pation } \\
(\mathrm{N}=16)\end{array}$ & \\
\hline $\begin{array}{l}\text { Asbestos } \\
\text { exposure } \\
\text { confirmed }\end{array}$ & 9 & 1 & 2 & 1 & 1 & 1 & 1 & 4 & 1 & 1 & 1 & 1 & - & - & - & 1 & 1 & 26 \\
\hline $\begin{array}{l}\text { Asbestos } \\
\text { exposure } \\
\text { denied }\end{array}$ & - & - & - & - & - & - & - & 1 & - & - & - & - & 1 & - & - & - & - & 2 \\
\hline $\begin{array}{l}\text { Asbestos } \\
\text { exposure } \\
\text { unknown }\end{array}$ & - & - & - & - & - & - & - & 1 & - & - & - & - & 1 & 4 & 1 & - & 15 & 22 \\
\hline $\begin{array}{l}\text { Pleural } \\
\text { plaques }\end{array}$ & 2 & 1 & 1 & 1 & - & - & 1 & 1 & 1 & - & 1 & 1 & - & - & - & - & - & 9 \\
\hline
\end{tabular}


which an inquiry into possible exposure to asbestos was carried out, the patients had indeed been exposed earlier. The findings in the literature review point in the same direction. All of the publications are case reports, and it is likely that there is a tendency to stress the importance of the ergot drug in these circumstances and perhaps unconsciously disregard other exposures.

Some of the ergotamine alkaloids are produced by the fungus Claviceps purpurea, which grows on various members of the grass family in the temperate zones of the world. Particularly oat and barley, but also wheat and rye, can be affected. If spring and early summer are cool and wet, the fungus has maximal growth possibilities. The fungus hyphae can contaminate the crop; the
Table 3. Clinical data for the 50 patients with pleuropulmonary side effects related to ergot alkaloids and reported to the Swedish Registry for Side Effects of Medical Drugs.

\begin{tabular}{lcccc}
\hline Drug & $\begin{array}{c}\text { Age } \\
\text { (years) }\end{array}$ & $\begin{array}{c}\text { Dose } \\
\text { per day } \\
(\mathrm{mg})\end{array}$ & $\begin{array}{c}\text { Years } \\
\text { treated } \\
\text { with drug }\end{array}$ & $\begin{array}{c}\text { Mean time } \\
\text { from first } \\
\text { asbestos } \\
\text { exposure to } \\
\text { occurrence } \\
\text { of lesion } \\
\text { (years) }\end{array}$ \\
\hline Bromocriptine & 64 & $2.5-45$ & $0.4-10$ & 43 \\
Dihydroergotamine & 65 & $10-30$ & $0.4-25$ & 48 \\
Ergotamine & 63 & Varying & $>10$ &.. \\
Cabergoline & 70 & $2-8$ & $0.5-2$ & 33 \\
\hline Total & 65 &.$\cdot$ & $0.4->10$ & 44 \\
\hline
\end{tabular}

Table 4. Literature review 1968-2003: pleuropulmonary side effects of ergot drugs and exposure to asbestos.

\begin{tabular}{|c|c|c|c|c|c|}
\hline Drug & $\begin{array}{l}\text { Asbestos } \\
\text { exposure } \\
\text { confirmed }\end{array}$ & $\begin{array}{l}\text { Asbestos } \\
\text { exposure } \\
\text { denied }\end{array}$ & $\begin{array}{l}\text { Asbestos } \\
\text { exposure } \\
\text { unknown }\end{array}$ & Total & References \\
\hline \multicolumn{6}{|c|}{ Methysergide } \\
\hline Men & 3 & 1 & 11 & 15 & $\begin{array}{l}\text { Kok-Jensen \& Lindeneg, } 1970 \text { (3); Dunn \& Sloan, } 1973 \text { (4); Akoun et al, 1975, } \\
\text { (5); Mondrup \& Nielsen, } 1979 \text { (6);Gefter et al, } 1980 \text { (7); Lambard et al, } 1981 \\
\text { (8); Hansen et al, } 1986 \text { (9); Muller et al, } 1991 \text { (10); Caes et al, } 1997 \text { (11) }\end{array}$ \\
\hline Women & 0 & 1 & 11 & 12 & $\begin{array}{l}\text { Kok-Jensen \& Lindeneg, } 1970 \text { (3); Gefter et al, } 1980 \text { (7); Hansen et al, } 1986 \text { (9); } \\
\text { Mondrup \& Nielsen, } 1979 \text { (6) }\end{array}$ \\
\hline Total & 3 & 2 & 22 & 27 & \\
\hline \multicolumn{6}{|c|}{ Ergotamine } \\
\hline Men & 0 & 0 & 6 & 6 & Ibsen \& Lindeneg, 1979 (12); Taal et al, 1983 (13) \\
\hline Women & 0 & 1 & 3 & 4 & Ibsen \& Lindeneg, 1979 (12); Robert et al, 1984 (14); Allen et al, 1994, (15) \\
\hline Total & 0 & 1 & 9 & 10 & \\
\hline \multicolumn{6}{|c|}{ Dihydroergotamine } \\
\hline Men & 0 & 0 & 0 & 0 & \\
\hline Women & 1 & 0 & 1 & 2 & Malaquin et al, 1989 (16); Pfitzenmeyer et al, 1996 (17) \\
\hline Total & 1 & 0 & 1 & 2 & \\
\hline \multicolumn{6}{|c|}{ Bromocriptine } \\
\hline Men & 24 & 5 & 22 & 51 & $\begin{array}{l}\text { Hillerdal et al, } 1997 \text { (1); Knoop et al, } 1997 \text { (2); Bottcher \& Gron, } 1981 \text { (18); } \\
\text { LeWitt \& Calne, } 1981 \text { (19); Verget et al, } 1984 \text { (20); Douvier et al, } 1985 \text { (21); } \\
\text { Wiggins \& Skinner, } 1986 \text { (22); Mouysset et al, } 1986 \text { (23); Tornling et al, } 1986 \\
\text { (24); Ward et al, } 1987 \text { (25); McElvaney et al, } 1988 \text { (26);Kinnunen \& Viljanen, } \\
1988 \text { (27), Diot et al, } 1990 \text { (28); Todman et al, } 1990 \text { (29); Bhatt et all, 1991 (30); } \\
\text { Hely et al, 1991 (31); Vinge et al, } 1994 \text { (32); Klaassen et al, } 1996 \text { (33); Schmid } \\
\text { et al, } 1994 \text { (34); Messiaen et al, } 1996 \text { (35); Blomqvist \& Palmér, 1995 (48) }\end{array}$ \\
\hline Women & 0 & 0 & 1 & 1 & Todman et al, 1990 (29) \\
\hline Total & 24 & 5 & 23 & 52 & \\
\hline \multicolumn{6}{|l|}{ Pergolide } \\
\hline Men & 4 & 0 & 6 & 10 & $\begin{array}{l}\text { Shaunak et al, } 1999 \text { (36); Varsano et al, } 2000 \text { (37); Danoff et al, } 2001 \text { (38); } \\
\text { Kastelik et al, } 2002 \text { (39); Bleumink et al, } 2002 \text { (40); Hirani et al, } 2003 \text { (41) }\end{array}$ \\
\hline Women & 0 & 0 & 1 & 1 & Kastelik et al, 2002 (39) \\
\hline Total & 4 & 0 & 7 & 11 & \\
\hline \multicolumn{6}{|c|}{ Others (nicergoline, cabergoline and dihydroergocristine) } \\
\hline Men & 0 & 5 & 2 & 7 & $\begin{array}{l}\text { Malaquin et al, } 1989 \text { (16); Blomqvist \& Palmér, } 1995 \text { (48); Frans et al, } 1992 \\
\text { (42); Ling et al, } 1999 \text { (43) }\end{array}$ \\
\hline Women & 0 & 2 & 0 & 2 & Kastelik et al, 2002 (39) \\
\hline Total & 0 & 7 & 2 & 9 & \\
\hline \multicolumn{6}{|c|}{ Grand total } \\
\hline Men & 31 & 11 & 47 & 89 & \\
\hline Women & 1 & 4 & 17 & 22 & \\
\hline Total & 32 & 15 & 64 & 111 & \\
\hline
\end{tabular}


ergotamines are not destroyed by cooking or baking and can thus be ingested with bread or other foodstuffs (44). Ergotamines are potent vasoconstrictors and also dopamine agonists. With intoxication, hallucinations, gangrene, loss of limbs, and death occur. The first recorded major outbreak of ergotism (ie, toxic effects of high doses) occurred in the Rhine valley in 857, when thousands of people died after eating bread made from infected rye. In Limoges in France, 40000 died in the year 943. Larger or smaller outbreaks have occurred throughout history up to the 1920s in the Soviet Union, and as late as in 1951 four deaths occurred in France (45). It has affected history in various ways; for instance, in 1721 Peter I of Russia had to abandon his attack on the Ottoman Empire because most of his men and horses had died or gone mad from eating infected rye bread.

The potent effects of the ergotamines caused it to be used in medicine at an early stage. The vasoconstricting effects are used to fight vascular headaches such as migraine (ergotamine, methysergide) and hypotonia (dihydroergotamine), and the dopamine agonist effect is important in treating Parkinson disease (bromochriptine, pergolide). The first reports on pleuropulmonary fibroses caused by ergotamines came in 1966 (46), and the symptoms, radiological findings, and laboratory findings were well described 10 years later (47).

The first report of the possible combined effect of asbestos and ergot alkaloids was published in 1995 in Sweden, when two cases were described (48); these cases were not reported to the registry. In 1997, two independent reports were published, one of 11 Swedish and 4 Australian cases (1) and one of 2 patients from The Netherlands (2). Four of the eleven Swedish cases were reported to the registry and are thus included in our present study.

Parkinson disease is fairly common, especially in elderly age groups. The prevalence is the same for men and women (49). Except for the very slight cases, bromocriptine has, for many years, been standard treatment. The fact that it is almost only men (in this study, 37 men versus 1 woman; in the literature study, 51 men versus 1 woman) who suffer from ergotamine-related side effects strongly suggests an occupational or possibly a hormonal co-factor.

The most common reason for using ergotamine is migraine. As seen from the reported cases, this drug seems rarely to cause pleuropulmonary side effects, probably due to its often very intermittent use. The case reported to the registry was a woman who was paraoccupationally exposed to asbestos. A few years ago one of us $(\mathrm{GH})$ saw a woman who, for 4 years, had taken one to three pills a day for her chronic headache. First, after specific questioning, she admitted this abuse, and both her headache and the symptoms from her pleuro-pulmonary reaction disappeared when she was persuaded to stop this "treatment". She denied all asbestos exposure, but pleural lavage showed asbestos bodies highly suggestive of significant exposure to asbestos (50). This case was never reported to the registry. It illustrates the difficulties in ascertaining asbestos exposure in some cases, and how sometimes even the drug exposure is not self-evident.

The mechanisms of the pleural and pulmonary lesions caused by ergotamine or asbestos are unknown. The ergotamine side effects have many systemic features: fatigue, anemia, activated inflammatory parameters such as a high erythrocyte sedimentation rate, weight loss, and the like (1). Thus some kind of immune response has been triggered by the drug. In the experimental setting, bromocriptine has been shown to have immuno-modulating effects, mainly immunosuppressive $(51,52)$. Bromocriptine can also be used for treating rheumatic and autoimmune diseases (53).

Asbestos-related pleural lesions are of two kinds: pleural plaques, which are slowly growing localized thickenings of the parietal pleura, causing no systemic effects, and diffuse pleural fibrosis, which involves the underlying lung parenchyma, can be associated with pleural effusion, and has a more sudden appearance (54). However, systemic effects such as anemia, fatigue, and weight loss, are not seen.

Autoimmune diseases can be defined as "a clinical syndrome caused by the activation of $\mathrm{T}$ cells or B cells, or both, in the absence of an ongoing infection or other discernible cause" (55). In a genetically predisposed person, some trigger is usually required for such a disease. We suggest that the combination of asbestos and ergot drugs can cause a systemic reaction, similar to an autoimmune disease, which, however, is self-limiting once the ergotamines are stopped but, as a rule, leaves fibrotic scarring causing a restrictive lung disease. If treatment continues, the disease can probably be fatal. In the Swedish registry, at least two patients continued with the drug until death, and the intense general inflammatory reaction clearly at least contributed to the outcome.

An interesting parallel to the cases described is fescue toxicosis among cattle. Steers grazing on entophyteinfected tall fescue have chronic intoxication from many different ergot alkaloids causing, among other things, decreased weight gain, rough hair coats, and pyrexia. If challenged with intravenous lipopolysaccharide, they show an increased response with higher levels of TNFalpha (tumor necrosis factor-alpha), cortisol, and IGF1 (insulinlike growth factor-1) (56).

It is of certain interest that the first side effects described from methysergide therapy was retroperitoneal fibrosis (46) and that this rare disease has also been suggested to occur after asbestos exposure (57-59). 
A recently published study definitely confirmed this association (60). Fortunately, this is a very rare disease, but it seems likely that, even in these cases, asbestos and ergotamines may be co-factors.

In summary, we believe that enough evidence exists to postulate a combined effect of earlier asbestos exposure and the intake of ergot drugs as a cause of pleuropulmonary lesions. We suggest that, before an ergotamine is prescribed for a patient, an occupational history, particularly regarding exposure to asbestos, should be taken, and a chest roentgenogram and a pulmonary function test, including total lung volume, should also be performed. Asbestos-exposed patients, especially if they have pleural plaques, should be followed carefully, and, if any signs of pleurisy or restrictive lung disease develop, the drug should be discontinued. We also believe that a high erythrocyte sedimentation rate is an early warning sign. The diagnosis is important, because, if treatment with the drug continues, severe restrictive disease, anemia, fatigue, and the like can develop, and the disease can be fatal.

\section{References}

1. Hillerdal G, Lee J, Blomkvist A, Rask-Andersen A, Uddenfeldt M, Koyi H, et al. Pleural disease during treatment with bromocriptine in patients previously exposed to asbestos. Eur Respir 1997;10:2711-5.

2. Knoop C, Mairesse M, Lenclud C, Gevenois PA, De Vuyst P. Pleural effusion during bromocriptine exposure in two patients with pre-existing asbestos pleural plaques: a relationship? Eur Respir J 1997;10:2898-901.

3. Kok-Jensen A, Lindeneg O. Pleurisy and fibrosis of the pleura during methysergide treatment of hemicrania. Scand J Respir Dis 1970;51:218-22.

4. Dunn JM, Sloan H. Pleural effusion and fibrosis secondary to Sansert administration. Ann Thorac Surg 1973;15:295-8.

5. Akoun G, Herson S, Huchon G, Marsac JH. Fibrose pleuropulmonaire au méthysergide avec complexes immuns circulants. Nouv Presse Méd 1975;39:2809.

6. Mondrup K, Nielsen HK. Metysergidinducerede fibroser. Ugeskr Laeger 1979;141:284-7.

7. Gefter WB, Epstein DM, Bonavita JA, Miller WT. Pleural thickening caused by Sansert and Ergotrate in the treatment of migraine. Am J Roentgenol 1980;135:375-7.

8. Lambard JV, Vincent J, Roge JM, Akoun G, Michel PL. Fibrose pleuro-pulmonaire au méthysergide. Nouv Presse Méd 1981;10:2440-1.

9. Hansen G, Abildgaard U, Skarpaas IJK. Alvorlige bivirkninger av methysergid. Tidsskr Nor Legeforen 1986;26:2160-2.

10. Muller R, Weller P, Chemaissani A. Pleurafibrose als Nebenwirkung einer langjährigen Methysergid-Therapie. Dtsch Med Wochenschr 1991;116:1433-6.

11. Claes I, Slabbynck H, Bedert L, Galdermans D, Dierckx I, Coolen D. A 47 year old man with nonproductive cough and right-sided chest pain. Eur Respir J 1997;10:2171-3.

12. Ibsen KK, Lindeneg O. Ergotaminbehandling og pleuritis.
Ugeskr Laeger 1979;141:860.

13. Taal BG, Spierings ELH, Hilvering C. Pleuropulmonary fibrosis associated with chronic and excessive intake of ergotamine. Thorax 1983;38:396-8.

14. Robert M, Derbaudrenghien JP, Blampain JP, Lamy F, Meyer $\mathrm{Ph}$. Fibrotic processes associated with long-term ergotamine therapy. New Engl J Med 1984;311:601-2.

15. Allen MB, Tosh G, Walters G, Muers MF. Pleural and pericardial fibrosis after ergotamine therapy. Respir Med 1994;88:67-9.

16. Malaquin F, Urban T, Ostinelli J, Ghedira H, Lacronique J. Pleural and retroperitoneal fibrosis from dihydroergotamine. N Engl J Med 1989;321:1760.

17. Pfitzenmeyer P, Foucher P, Dennewald G, Chevalon B, Debieuvre D, Pensa B, et al. Pleuropulmonary changes induced by ergoline drugs. Eur Respir J 1996;9:1013-9.

18. Bottcher J, Gron J. Pleuropulmonale forandringer ved bromokriptinbehandling af parkinsonisme. Ugeskr Laeger 1981;143:2648-9.

19. LeWitt PA, Calne DB. Letter to the editor. Lancet 1981;i:445.

20. Vergeret J, Barat M, Taytard A, Bellvert P, Domblides Ph, Douvier JJ, et al. Fibrose pleuro-pulmonaire et bromocriptine. Sem Hop Paris 1984;60:641-744.

21. Douvier JJ, Vergeret J, Taytard A, Brottier E, Domblides Ph, Dubos F, et al. La bromocriptine dans la maladie de Parkinson: toxicité pleuro-pulmonaire. Ann Méd Interne (Paris) 1985;136:416-8.

22. Wiggins J, Skinner C. Bromocriptine induced pleuropulmonary fibrosis. Thorax 1986;41:328-30.

23. Mouysset B, Montastruc JL, Rostin M, Caratero A, Sorbette F, Leophonte P, et al. Bromocriptine et fibrose pleuropulmonaire. Therapie 1986;41:73-5.

24. Tornling G, Unge G, Axelsson G, Noring L, Granerus AK. Pleuropulmonary reactions in patients on bromocriptine treatment. Eur J Respir Dis 1986;68:35-8.

25. Ward CD, Thompson J, Humby MD. Pleuropulmonary and retroperitoneal fibrosis associated with bromocriptine treatment. J Neurol Neurosurg Psychiatry 1987;50:1706-7.

26. McElvaney BG, Wilcox PG, Churg A, Fleetham JA. Pleuropulmonary disease during bromocriptine treatment of Parkinson's disease. Arch Intern Med 1988;148:2231-6.

27. Kinnunen E, Viljanen A. Pleuropulmonary involvement during bromocriptine treatment. Chest 1988;94:1034-6.

28. Diot E, Diot P, Le Rolland A, Jonville AP, Lasfargues G, Lemaire E, et al. Epanchements pleuraux induits par la bromocriptine. Rev Mal Respir 1990;7:175-7.

29. Todman DH, Oliver WA, Edwards RL. Pleuropulmonary fibrosis due to bromocriptine treatment for Parkinson's disease. Clin Exp Neurol 1990;27:79-82.

30. Bhatt MH, Keenan SP, Fleetham JA, Calne DB. Pleuropulmonary disease associated with dopamine agonist therapy. Ann Neurol 1991;30:613-6.

31. Hely MA, Morris JGL, Lawrence S, Jeremy R, Genge S. Retroperitoneal fibrosis, skin and pleuropulmonary changes associated with bromocriptine therapy. Aust $\mathrm{N} \mathrm{Z} \mathrm{J} \mathrm{Med}$ 1991;21:82-4.

32. Vinge E, Odin P, Hansson L, Widner H, Lindvall O. Pravidel kan ge lungförändringar. Läkartidningen 1994;91:4116-8.

33. Klaassen RJL, Troost RJJ, Verhoeven GT, Krepel HP, van der Lely AJ. Suggestive evidence for bromocriptine-induced pleurisy. Neth J Med 1996;48:232-6.

34. Schmid PA, Suter T, Speich R, Eberli F, Greminger P. Bromocriptin-induzierte Pleuropneumopathie. Dtsch Med Wo- 
chenschr 1994;119:1543-6.

35. Messiaen T, Lefebvre C, Weynand B, Pieters T. Épanchehement pleural et importants oedèmes des membres inférieurs induits par la bromocriptine. Rev Méd Interne 1996;17:6803.

36. Shaunak S, Wilkins A, Pilling JB, Dick DJ. Pericardial, retroperitoneal, and pleural fibrosis induced by Pergolide. J Neurol Neurosurg Psychiatry 1999;66:79-81.

37. Varsano S, Gershman M, Hamaoui E. Pergolide-induced dyspnea, bilateral pleural effusion and peripheral edema. Respiration 2000;67:580-2.

38. Danoff S, Grosso ME, Terry PB, Flynn JA. Pleuropulmonary disease due to pergolide use for restless legs syndrome. Chest 2001;120:313-6.

39. Kastelik JA, Aziz I, Greenstone MA, Thompson R, Morice AH. Pergolide-induced lung disease in patients with Parkinson's disease. Respir Med 2002;96:548-50.

40. Bleumink GS, van der Molen-Eijgenaam M, Strijbos JH, Sanwikarja JH, van Puijenbroek E, Stricker BHC. Pergolideinduced pleuropulmonary fibrosis. Clin Neuropharmacol 2002;25:290-3

41. Hirani N, Forzley B, Langridge J, Bayliff C, McCormack DG. Pergolide-induced pleural disease in a patient with asbestos exposure. Chest 2003;124 suppl 276S.

42. Frans E, Dom R, Demedts M. Pleuropulmonary changes during treatment of Parkinson's disease with a long-acting ergot derivative, cabergoline. Eur Respir J 1992;5:263-5.

43. Ling LH, Ahlskog JE, Munger TM, Limper AH, Oh JK. Constrictive pericarditis and pleuropulmonary disease linked to ergot dopamine agonist therapy (Cabergoline) for Parkinson's disease. Mayo Clin Proc 1999;74:371-5.

44. Webster J. Introduction to fungi. Cambridge (UK): Cambridge University Press; 1970. p 234-40.

45. Trager J. The peoples chronology: revised and updated version. New York (NY): Henry Holt and Company; 1994.

46. Graham JR, Suby HI, LeCompte PR, Sadowsky NL. Fibrotic disorders associated with methysergide therapy for headache. N Engl J Med 1966;274:360-8.

47. Akoun G, Herson S, Huchon G, Marsac J. Les fibroses pleuropulmonaires du Méthysergide. Sem Hop Ther Paris 1976;52:9-13.

48. Blomqvist AM, Palmér M. Asbestos, ergot alkaloids, and pleuritis. Int J Occup Med Toxicol 1995;4:277-83.

49. de Rijk MC, Tzourio CM, Breteler MMB, Dartigues JF, Amaducci L, Lopez-Sousa S, et al. Prevalence of parkinsonism and Parkinson's disease in Europe: the EUROPARKINSON collaborative study. J Neurol Neurosurg Psychiatry 1997;62:10 5 .

50. de Vuyst P, Dumortier P, Moulin E, Yurassowsky N, Jernault JC. Diagnostic value of asbestos bodies in bronchoalveolar lavage fluid. Am Rev Respir Dis J 1987;136:1219-24.

51. Morikawa K, Oseko F, Morikawa S. Immunosuppressive activity of bromocriptine on human $\mathrm{T}$ lymphocyte function in vitro. Clin Exp Immunol 1994;95:514-8.

52. Blank M, Krause I, Buskila D. Bromocriptine immunomudulation of experimental SLE and primary antiphospholipid syndrome via induction of non-specific T suppressor cells. Cell Immmunol 1995;162:114-22.

53. McMurray RW. Bromocriptine in rheumatic and autoimmune diseases. Semin Atrhritis Rheum 2001;31:21-32.

54. Hillerdal G. Asbestos-related pleural disease. Semin Respir Med 1987;9:65-74.

55. Davidson A, Diamond B. Review article: autoimmune diseases. N Engl J Med 2001;345:340-50.

56. Filipov NM, Thompson FN, Stuedeman JA, Elsasser TH, Kahl S, Sharma RP, et al. Increased responsiveness to intravenous lipopolysaccharide challenge in steers grazing endophyte-infected tall fescue compared with steers grazing endophyte-free tall fescue. J Endocrinol 1999;163:213-20.

57. Maguire GP, Meggs LG, Addonizio J, Del Guercio RLM. Association of asbestos exposure, retroperitoneal fibrosis, and acute renal failure. NY State J Med 1991;91:357-9.

58. Boulard JC, Hanslik T, Doleris LM, Prinseau J, Baglin A. Asbestos and idiopathic retroperitoneal fibrosis. Lancet 1995;345:1379.

59. Sauni R, Oksa P, Järvenpää R, Parker JE, Roto P. Asbestos exposure: a potential cause of retroperitoneal fibrosis. Am J Ind Med 1998;33:418-21.

60. Uibu T, Oksa P, Auvinen A, Honkanen E, Metsärinne K, Saha $\mathrm{H}$, et al. Asbestos exposure as a risk factor for retroperitoneal fibrosis. Lancet 2004;363:1422-6.

Received for publication: 18 November 2004 